International Journal of Oceans and Oceanography

ISSN 0973-2667 Volume 14, Number 1 (2020), pp. 1-8

(C) Research India Publications

https://dx.doi.org/10.37622/IJoo/14.1.2020.1-8

\title{
Development of Mouth Opening and Digestive Enzyme Activities in Sheatfish (Ompok hypopthalmus) Larvae
}

\author{
Usman Muhammad Tang1), Hamdan Alawi' ${ }^{1)}$, Heri Masjudi' ${ }^{1)}$, Muhammad Fauzi ${ }^{2}$ ) \\ ${ }^{1}$ Department of Aquaculture, Faculty of Fisheries and Marine Sciences, \\ University of Riau, Pekanbaru, Indonesia; \\ ${ }^{2}$ Department of water resource management, Faculty of Fisheries and Marine Sciences, \\ University of Riau, Pekanbaru, Indonesia.
}

Corresponding author's e-Mail: heri_masjudi@yahoo.com

\begin{abstract}
The objectives of this research was 1) to measure the development of mouth opening width and 2) to analyze the digestive enzyme activities. The research was conducted from April to November 2017 in the Hatchery Laboratory, Faculty of Fisheries and Marine Sciences, University of Riau. The results showed that the increase of mouth opening and the rate of gut evacuation of sheatfish larvae was due to the increase of digestive enzyme activities and feed consumption rate.
\end{abstract}

Keywords: Mouth opening, digestive enzyme activities, sheatfish larvae

\section{INTRODUCTION}

Aquacuture fish commodities in Indonesia were still dominated by introduced species, i.e carp, Cyprinus carpio ; Tilapia, Oreochromis niloticus African catfish, Clarias gariepinus, tambaqui, Cllossoma macropomum, and siamise catfish, Pangasius hypopthalmus.. Aquaculture species reared in floodplain wetland developeb by Unversity of Riau and Freshwater Research Institute Sukabumi was river catfish (mystus nemurus) (Tang. 2011). The other potential species which finely grow in the floodplain wetland (low pH) is sheatfish (Ompok hypopthalmus).

Ikan selais, sheatfish, is one of the freshwater species known and popular in the region of Kalimantana and sumatera. The demand of this species mostly derive from the natural catch (river, wetland and lake). Due to the economic value, the natural catching of the species was intensively done even in the spawning season. The effect of the unregulated catching, the population of this species has been seriously threated, while the domestication of this species has not been fully undertaken. 
The critical time of aquaculture phase is the change of endogenous to exogenous feeding (Tang, et.al, 2000) and the weaning time from feeding natural to artificial food. The changing of food type and size are determined by the digestive enzymatic activities and mouth opening width. Some researches on the activities of digestive enzyme and development of mouth opening width in fish larvae were done in Indian major carp Labeo rohita (Chakrabarti et.al. 2006), riverine catfish, mystus nemurus (Tang, 2000; Srichanun et.al., 2012; El Haq et al. 2012), Scophthalmus maximus (Cousin et.al. 1987), common carp, Cyprinus carpio (Farhoudi et.al. 2013), cobia, Rachycentron canadum (Faulk et.al, 2007), atlantic halibut, Hippoglossus hippoglossus (Gawlicka et.al. 2000), rainbow trout (Kawai et.al. 1973), grouper, Epinephelus fuscoguttatus (Melianawati et.al., 2011), Cyprinid (Tameemi, 2010). Investigation on the relation of mouth width and food size was reported in cyprinid fish ((Dabrowski et.al., 1948), milk fish, Chanos chanos, seabass, Lates calcarifer, and rabbitfish, Siganus gutatus larvae (Duray, \& Kohno, 1990).

\section{MATERIALS AND METHODS}

The research was conducted in April-December 22016 at The aquaculture Technology Lab, Faculty of Fisheries and Marine Sciences, University of Riau.

Source of larvae, Sheatfish larvae were obtained from induced spawning using 1.1 $\mathrm{ml} / \mathrm{kg}$ OVAPRIM. The fertilized eggs were incubated in a $60-\mathrm{L}$ glass aquaria. The eggs wee hatched after 18-22 hour incubation.

Development of morphological and mouth width larvae. Morphological development of larvae was observed using binocular microscope. One of the morphological development observed was fin development. The observation was done daily until reaching full developed. The maximum mouth width of larvae was determined using the equation :

$\mathrm{D}=\sqrt{ } 2 \mathrm{AB}$, where, $\mathrm{D}=$ Mouth Depth ( Width); $\mathrm{AB}=$ Upper jaw length. (Shirota, 1977).

Measurement of enzymatic activities, Enzymatic activities analyzed were amylase, lipase, and protease. Activity of lipase, protease and amylase analyzed and measured based on Borlongan (1990), Bergermeyer et al. (1983) and Worthington (1993) method, respectively.

$$
\text { Calculation }=\frac{\text { mol moltose produced }}{\text { mg of the enzyme in the reaction mixture for } 3 \text { minutes. }}
$$

Enzymatic development was measured and sampled 5 times: 0 days old larvae (after yolk sac absorbed)done after , 7 days , 15 days, 23 dasy and 31 days old larva. The larvae was sampled several hour after feeding, The sampled larva were keep in a vial and stored in freezer $\left(-1^{\circ} \mathrm{C}\right)$. Enzymatic activities was investigate $=\mathrm{d}$ in the Microbiology and Biochemistry Laboratory, Bilogial Sciences Study Center, Bogor Agriculture Institute. 


\section{RESULTS AND DISCUSSION}

\section{Morphological development of sheatfish larva}

The new hatch sheatfish larvae was passive, transparent and tended to collectively be in the corner of the tank. The mouth was unopened; yolk sac was full. In the second days (28-30 das after hatching), the mouth was gradually developed and opened. In this times. Three days old larva begin to looking for food ( 50-52 hours after hatching). Morphological development of sheatfish larvae sees in Figure 1.
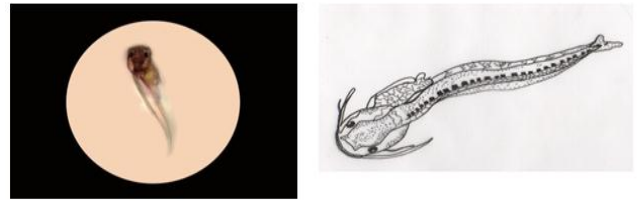

A
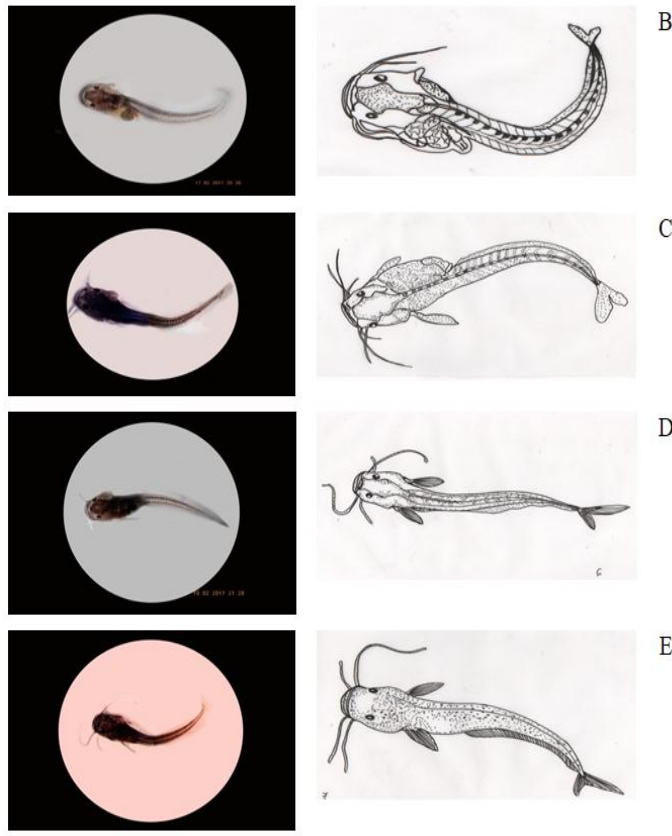

Figure 1. Morphological development of sheatfish larvae (Ompok hypopyhalmus Blkr.). $A=3$ days old, fin and barbell was distinct., the yolk sac was gradually disappeared , $B=4$ days old; barbell (mandibular and maxillary) grow longer, anal fin, tail and caudal fin formation were in progress, $C=5$ days old; Mouth was fully developed and functional; All fins were function; the larvae was free swimming. Yolk substance was fully absorbed; , $D=$ Six days old; All fin were differentiated. The larvae swimming more progressive and collective in di the corner of the tank. E = Seven Days old. The larva look like the young fish.

The newly hatch larvae of sheatfish was transparent, unopened mouth, distinctive fins, and pigmented eye. Rudiments of maxillary and mandibular barber were also noticed. These descriptions were also noted in riverine catfish, Mystus nemurus C.V. (Tang, 2000), aand in African catfish, Clarias gariepinus (Bruton in Tang 2000). Mouth was gradually developed and begin external feeding at three days pst hatching (dph) 
At thee day old larva, the yolk sac was slowly disappeared from the third day onward, as also reported in Ompok pabda (Sarma, et al. 2012). Pectoral fin, caudal fin and tail was started to form. Maxillary and mandibular barber were also formed and getting longer at 5 days old larvae. The rudiment of dorsal fin was noted at the very beginning of stage, and developed well at the seventh day old with 4 rays. According to Tang and Affandi (2004), the newly hatched larvae has a pigmented eye, and increase as the larvae grow. At the second day old, the aye started functional, gill appeared and full developed at the tenth day old larvae.

The development of fish larvae was generally was divided into 2 phase (Effendi, 1979), prelarvae and post larvae. Aral et al. (2011) described the two phase of larval development of freshwater fish larvae as follow; Prelarval Phase: It is the period which starts from coming out from egg to the end of absorption of yolk sac. The most important charecteristic of prelarval stage is the existence of yolk sac. At the beginning of the prelarval phase mouth, anus and digestive tube is like straight pipe. Head is smaller than body, eyes are big and non-pigmented. The double-walled sacs in the form of external sensory organ of balance otoliths are on both sides of the head. Nostrils are not developed under eye. Towards the end of this phase mouth and anus opens. Eyes are pigmented and nutrition mouth starts at the outside part. During prelarval phase only the pectoral fins which appears. Postlarval Phase: It is the time starts after absorption finished to the end of metamorphosis. The length of the time changes species to species. It varies to species according to shape, size, body ratio, fin size, pigmentation in different sizes and order, shape and time of organ formation in postlarval phase. Some organs form in postlarval phase in order to make easier to stay pelagic. Nutrition takes place entirely from outside in postlarval phase. Nutrition are phytoplankton, zooplancton or mixture of both.

The average of mouth opening width of sheatfish larvae at different observation time as seen in Table 1)

Table 1. Mouth width of sheatfish larvae (Ompok hypopthalmus Blkr) at different age

\begin{tabular}{cl}
\hline Age (days) & Mouh width $(\mathrm{mm})$ \\
\hline 7 & $1.45 \pm 0.10^{\mathrm{b}}$ \\
15 & $2.08 \pm 0.08^{\mathrm{cd}}$ \\
23 & $2.16 \pm 0.06^{\mathrm{cd}}$ \\
31 & $2.68 \pm 0.05^{\mathrm{e}}$ \\
\hline
\end{tabular}

The position of mouth of sheatfish larvae was subterminal. The size increased from $1.45 \mathrm{~mm}$ for $7 \mathrm{dph}$ (day post hatching) larvae to $2.68 \mathrm{~mm}$ for $31 \mathrm{dph}$. The increasing of mouth width and the structure of mouth are important for the larvae related to feeding behavior and feeding mode. (Tang, 2000; Shirota in Tang, 2000: El Hag et al. 2012). 


\section{Enzyme activities of amylase, lipase and protease}

Total enzyme activities of Amylase, lipase and protease (IU/ml) at different age of sheafish larvae, Ompok hypothalamus are presented at Table2.

Table 2. Enzymatic Activities of Amylase (EAA), Lipase (EAL) and Protease

(EAP) sheatfish larve for different age

\begin{tabular}{cc|c|c}
\hline $\begin{array}{c}\text { Age } \\
(\text { day })\end{array}$ & $\begin{array}{c}\text { EAA } \\
(\mathrm{IU} / \mathrm{ml})\end{array}$ & $\begin{array}{c}\text { EAL } \\
(\mathrm{IU} / \mathrm{ml})\end{array}$ & $\mathrm{E}(\mathrm{IU} / \mathrm{ml})$ \\
\hline 0 & $0.024 \pm 0.001$ & $0.216 \pm 0.006$ & $0.138 \pm 0.000$ \\
7 & $0.247 \pm 0.020$ & $0.235 \pm 0.002$ & $0.575 \pm 0.004$ \\
15 & $0.361 \pm 0.001$ & $0.243 \pm 0.006$ & $0.597 \pm 0.004$ \\
23 & $0.746 \pm 0.416$ & $0.261 \pm 0.004$ & $0.734 \pm 0.000$ \\
31 & $0.871 \pm 0.155$ & $0.297 \pm 0.000$ & $0.910 \pm 0.000$ \\
\hline
\end{tabular}

Activity of lipase enzyme for newly hatched larvae was higher than that of amylase and protease, then decrease when the larvae start exogenous feeding. The protease enzyme activity was higher than amylase. While the protease and amylase enzyme activities increased as the larvae grow. At the seventh day old larvae which totally fed on natural feed and artificial feed, the activity both protease and amylase enzyme increased significantly. The higher lipase enzyme for the newly hatched larvae probably due to higher content of lipid in the yolk sac. When larvae started exogenous feeding (Artemia nauplii or tubifex worm), the lipase enzyme activities did not significantly increase.

Activity of amylase enzyme was higher that it of lipase enzyme started from 7 days post hatching. This showed that carbohydrate content of natural food used during rearing period was high which was, in turn, able to stimulate the secretion and synthesis of amylase enzyme during larval development (Ma et al., 2005). This mean that sheatfish, Ompok hypopthalmus larvae has the high ability to utilize carbohydrate after yolk sac absorbed. . The similar high amylase enzyme activities was found in milkfish larvae (Haryati, 2003), Mystus nemurus (Srichanun et al. 2012), rohu, Labeo rohita (Chakrabarti et al. 2006). As the digestive tract develop, the fish larvae changed quickly in feeding behavior according to their feeding habit. (Savona et al., 2011).

The protease enzyme activity was higher than amylase enzyme at all ages of larvae. The activity was detected at one day old larvae and increased as the larvae grow. The higher protease enzyme activities at the endogenous phase (yolksac larvae) probably 
due to the protein hydrolysis process of yolk to produce free energy. Yolk sac of fish larvae contain high protein (Kamler, 1992), amino acid and lipid which were catabolized to produce energy. As the digestive tract develop, the activity of protease enzyme increase (Cousine et al., 1987). Enzyme activities tend increasing as the size of larvae are bigger. The digestive organs are fully developed and the larvae increase the food consumption at the exogenous phase of feeding (Kawai et al. 973.

\section{CONCLUSION}

Development of mouth width and digestive enzyme activities increased as the larva of sheatfish Ompok hypopthalus growed bigger. The mouth width increased from 1.45 $\mathrm{mm}$ for $7 \mathrm{dph}$ (day post hatching) larvae to $2.68 \mathrm{~mm}$ for $31 \mathrm{dph}$. Lipase enzyme activity was higher for newly hatched larvae. Protease and amylase enzyme activities increase as the size of larvae increase.

\section{REFERENCES}

[1] Aral, F., E. Şahınöz and Z. Doğu. 2011. Embryonic and Larval Development of Freshwater Fish. In Recent Advances in Fish Farms, Dr. Faruk Aral (Ed.), ISBN: 978-953-307-759-8, InTech, Available from: http://www.intechopen.com/books/recent-advances-in-fish-farms/embryonicand-larval-development-offreshwater-fish

[2] Arlia L. 1994. Pengaruh kadar protein pakan buatan terhadap pertumbuhan benih ikan Gurami (Osphronemus gouramy Lacepede) [Tesis]. Bogor (ID): Institut Pertanian Bogor.

[3] Bergmeyer, H. U. Grossl, M. dan Walter, H. E. 1983. Reagents for Enzymatic Analysis. In: HU Bergmeyer (ed.) Methods in Enzymatic Analysis. 2(3):274275

[4] Borlongan, L. G. 1990. Studies on the Digestive Lipases of Milkfish, Chanos chanos. Aquaculture. 89:315-325

[5] Chakrabarti R, Rathore RM \& Kumar S. 2006. Study of digestive enzyme activities and partial characterization of digestive proteases in a freshwater teleost, Labeo rohita, during early ontogeny. Aquaculture Nutrition. 12:35-43

[6] Cousin, J. C. B., F. Baudin-Laurencin \& J. Gabaudan. 1987. Ontogeny of Enzymatic Activities in Fed and Fasting Turbot, Scophthalmus maximus L. J. Fish Biol., 30: 15 - 33

[7] Dabrowski K., and R. Bardega, 1984. Mouth size and predicted food size preferences of larvae of three cyprinid fish species. Aquaculture. Volume 40, Issue 1, 1 July 1984, Pages 41-46

[8] Duray, M. N., \& Kohno, H. (1990). Development of mouth width and larval growth in three marine fish species. Philippine Journal of Science, 119(3), 
$237-245$

[9] Effendi, M. I., 1979. Metode Biologi Perikanan. Yayasan Dewi Sri. Bogor. 112 hal

[10] El Haq, G A, M.S. Kamarudin, C. R. Saad and S. K. Daud. 2012. Mouth Development of Malaysian River Catfish, Mystus nemurus (C\&V) Larvae. Journal of American Science, 8(1):271-276

[11] Farhoudi, AM Abedian Kenari, RM Nazari and Ch Makhdoomi. 2013. Changes of digestive enzymes activity in common carp (Cyprinus carpio) during larval ontogeny. Iranian Journal of Fisheries Sciences. 12(2):320-334

[12] Faulk CK, Benninghoff AD and Holt GJ. 2007. Ontogeny of the gastrointestinal tract and selected digestive enzymes in cobia Rachycentron canadum (L.). Journal of Fish Biology. 70:567583.doi:10.1111/j.10958649.2007.01330.x

[13] Gawlicka, A, B. Parent, M.H. Horn, N. Ross, I. Opstad, and O.J. Torrissen. 2000. "Activity of Digestive Enzymes in yolk-sac Larvae of Atlantic Halibut (Hippoglossus hippoglossus): Indication of Readiness for First Feeding". Aquaculture Journal Vol. 184:303-314

[14] Haryati. (2003). Respon larva ikan bandeng (Chanos chanos Forskal) terhadap pakan buatan dalam system perbenihan. (Disertasi) Bogor. Institut Pertanian Bogor.

[15] Kamler E. (1992). Early life history of fish: and energetics approach. Fish and Fisheries Series 4. Chapman and Hall. London-New York-Melbourne Madras. $267 \mathrm{p}$

[16] Kawai S. \& Ikeda S. (1973). Studies of digestive enzymes of fishes III. Development of digestive enzymes of rainbow trout after hatching and effect of dietary change on the activities of digestive enzymes in the juvenile stage. Bull. Jpn. Soc. ScL Fish., 39: 817-823

[17] Kottelat, M., A.J. Whitten, S.N. Kartikasari \& S. Wirjoatmodjo. 1993. Fresh Water Fishes of Western Indonesia and Sulawesi.

[18] Ma H., Cahu C., Zambonino-Infante J.L., Yu H., Duan Q., et al. (2005). Activities of selected digestive enzymes during larval development of large yellow croaker (Pseuosciaena crocea). Aquaculture, 245: 239-248.

[19] Melianawati R dan Pratiwi R. 2011. Pola aktivitas enzim pencernaan larva ikan kerapu macan (Epinephelus fuscoguttatus Forsskal, 1775). Jurnal Riset Akuakultur. 6:51-61

[20] Sarma. D, Das. J, Dutta. A and Goswami. U. C, 2012. Early embryonic and larval development of Ompok pabo with notes. European Journal of $\begin{array}{llll}\text { Experimental } & \text { Biology, } & 2012, & 2\end{array}$ (www.pelagiaresearchlibrary.com) 
[21] Savona B, Tramati C, Mazzola A. 2011. Digestive enzymes in larvae and juveniles of farmed Sharpsnout Seabream (Diplodus puntazzo) (Cetti, 1777). The Open Marine Biology Journal. 5(1):47-57. to

[22] Shirota, A. (1977). Studies on the mouth size of fish larvae. Method and conclusions only [Translation from: Bulletin of the Japanese Society of Scientific Fisheries 36, 353-368, 1970].

[23] Srichanun M, Tantikitti C, Vatanakul V and Musikarune P. 2012. Digestive enzyme activity during ontogenetic development and effect of live feed in green catfish larvae (Mystus nemurus Cuv. \& Val.). Songklanakarin Jurnal. Technol. 34(3):247-254

[24] Tameemi RA, Abdubaikul A and Salman NA. 2010. Comparative study of $\alpha$ amylase activity in three Cyprinid species of different feeding habits from Southern Iraq. Turkish Journal of Fisheries and Aquatic Sciences. 10:411414.doi:10.4194/trjfas.2010.0315

[25] Tang, U. M. 2000. Kajian Biologi Pakan dan Lingkungan Pada Awal Daur Hidup Ikan Baung (Mystus nemurus Cuvier \& Valeneiennes 1945). Thesis Institut Pertanian Bogor. Bogor

[26] Tang, U.M, dan Affandi R. 2004. Biologi Reproduksi Ikan. Unri Press. Pekanbaru. 110 pp.

[27] Tang, U.M. H.Alawi. P. Rengi, 2011. Pendugaan stock perikanan di Perairan Bengkalis. Bappeda Kabupaten Bengkalis. Bengkalis.

[28] Worthington V. 1993. Worthington Enzyme Manual. Enzymes and Related Biochemicals Worthington Chemical 